\title{
Kepercayaan Dan Praktik Shinto Dalam Anime Noragami
}

\author{
Brafangestu Candra D.N, Idah Hamidah, Diana Puspitasari \\ Program Studi Sastra Jepang Fakultas Ilmu Budaya Universitas Jenderal Soedirman \\ Jl. Dr. Soeparno Kampus Karangwangkal Purwokerto 53123 \\ Email: brafangestucandra@gmail.com
}

\begin{abstract}
Abstrak
Penelitian ini berjudul Kepercaya an dan Praktik Shinto da lam Anime Noragami. Tujuan daripenelitian ini adalah untuk mendeskripsikan bentuk-bentuk keperca yaan ma syarakat Jepang dilanjutkan dengan bentuk praktik ajaran Shinto yang terdapat pada anime Noragami berdasarkan konsep religi Koentjaraningrat. Data yang digunakan berupa dialog dan screenshoot adegan. Metode yang digunakan adalah deskriptif kualitatif, sedangkan teknik pengumpulan data yang digunakan a dalah teknik simak ca tat. Hasil penelitian menunjukkan bentuk-bentuk kepercayaan yang munculmeliputi kepercayaan terhadap Kami (dewa), roh orang mati, dan makhluk gaib berupa siluman (ayakshi), sedangkan untuk praktik keagamaan ditemukan bentuk berupa penyucian, persembahan, dan doa. Dapat disimpulkan bahwa konsep kepercayaan dalam ajaran Shinto di anime Noragami berupa pemahaman akan konsep roh serta kekuatan supernatural. Sedangkan untuk praktik keaga maannya berkonsep pa da kesucian a tau ketidaksucian serta meminta kepada dewa .
\end{abstract}

Kata kunci: anime; noragami; kepercayaan; shinto

\begin{abstract}
The aim of this research is to describe beliefs and Shinto practices in the anime Noragami based on the concept of religion by Koentjaraningrat and references from Danamdjaja, Nadroh and Azmi. The method used in this research is descriptive qualitative, the data collection technique used was a note taking technique. The data used are dialogues and screenshots. The data analysis technique was carried out by analyzing the dialogue in the anime noragami related to beliefs or Shinto practices. Found three concepts of beliefs from the anime includes beliefs in the existence of god, belief in the soul (spirit) of the dead, and belief in the evil spirit (ghost or monster). While Shinto rites were found, three practices include purification, offerings to gods and praying. The conclusions of this study about Japanese people's beliefs contained in the anime Noragami in the form of supernatural and soul (spirit) concept. For Shinto practices focus on purity, impurity and then ask God.
\end{abstract}

Keywords: anime; noragami; kepercayaan; shinto

\section{PENDAhULUAN}

Masyarakat Jepang percaya bahwa matahari, bulan, bintang, hujan, petir, gejalagejala alam, dan semua benda baik hidup maupun mati dianggap memiliki roh (spirit) yang diyakini memiliki daya kekuasaan yang berpengaruh bagi kehidupan mereka. Oleh karena itu mereka menyembah dan menjadikannya sebagai dewa. Para dewa digambarkan seperti manusia sebagaimana diceritakan dalam legenda terjadinya kepulauan Jepang dan memiliki daya kekuasaan. Daya-daya kekuasaan ini, baik yang terdapat dalam gejala alam maupun pada dewa dan menjadi objek pemujaan, diberi nama Kami (Djam'annuri dalam Nadroh dan Azmi, 2015:59). Sebagai kepercayaan asli bangsa Jepang Shinto telah merasuk ke dalam setiap sendi kehidupan yang kemudian menjadi pedoman hidup bagi mereka. Sejatinya Shinto merupakan agama tradisional warisan dari nenek moyang, sehingga tidak hanya rakyat Jepang yang harus mentaati agama tersebut tetapi pemerintahnya juga harus menjadi pewaris serta pelaksana utama dari agama ini. Paham ini timbul dari mitos-mitos yang berhubungan dengan terjadinya negara Jepang (Arifin dalam Mansur, 2011:35). 
Seiring berjalannya waktu praktik ajaran dan kisah para dewa Shinto mulai diangkat ke dalam layar perfilman bahkan hingga ke animasi yang dalam bahasa Jepang animasi biasa disebut dengan istilah anime. Salah satu anime yang di dalamnya mengangkat unsur mengenai bentuk kepercayaan serta praktik Shinto pada masyarakat Jepang di zaman modern adalah Noragami. Anime ini terdiri atas dua season dengan season pertama berjudul Noragami berjumlah total 12 episode tayang pada tahun 2014 dan untuk season kedua diberi judul Noragami Aragoto tayang pada tahun 2015 dengan jumlah 13 episode. Noragami menceritakan tentang seorang dewa liar tanpa kuil bernama Yato yang membuka jasa pelayanan kepada manusia dengan menuliskan nomor handphone-nya di area publik agar seseorang yang memerlukan bantuan atau pertolongan dapat segera menghubunginya. Yato akan datang kepada mereka yang telah menghubunginya dan mengabulkan permohonannya. Sama seperti ketika berdoa di kuil mereka yang meminta pertolongan kepada Yato akan memberikan uang lima yen sebagai persembahan. Sejak pertemuannya dengan seorang siswi bernama Hiyori Iki yang mengalami instan sleep (Shunkan bakusui, 瞬間爆睡) karena menjadi korban kecelakaan membawa Dewa Yato dan Yukine terjun dan terlibat lebih jauh ke dunia para dewa dan makhluk tidak kasatmata lain seperti siluman dan roh bersemayam. Tujuan dari penelitian yaitu untuk mendeskripsikan bentuk kepercayaan yang dilanjutkan dengan praktik ajaran Shinto yang tercemin dalam anime Noragami. Penelitian sebelumnya yang menjadi referensi peneliti yaitu dari Muflikhatun Afrianti (2018) berjudul "Dewi Izanami Dan Dewa Izanagi Dalam Agama Shinto Jepang (Studi Semiotik Dalam Film Noragami Aragoto)". Penelitian tersebut mengkaji tentang mitologi Dewi Izanami dan Dewa Izanagi dalam agama Shinto yang dianalisis menggunakan teori semiotik cinematographic language Christian Metz pada representasi Dewi Izanami dan Dewa Izanagi film Noragami Aragoto. Dari penelitian tersebut terlihat perbedaan dengan penelitian peneliti berdasarkan teori yang digunakan dan objek yang dikaji. Penelitian ini mengkaji tentang bentuk kepercayaan dan praktik dalam ajaran Shinto yang terdapat pada anime noragami dianalisis berdasarkan konsep religi Koentjaraningrat dan didukung konsep Shinto yang ada di masyarakat Jepang. Selain itu tidak seperti peneliti yang mengambil hampir seluruh episode pada setiap season anime noragami sebagai sumber data penelitian Afrianti hanya mengambil episode 8-13 dari anime noragami aragoto (season kedua dari anime tersebut). Atas dasar tersebut maka tujuan dari penelitian ini yaitu untuk mendeskirpsikan bentuk kepercayaan yang dilanjutkan dengan praktik ajaran Shinto yang tercermin di dalam anime Noragami.

\section{METODE}

Penelitian ini merupakan penelitian deskriptif yang menggunakan pendekatan kualitatif. Penelitian kualitatif adalah penelitian yang bermaksud untuk memahami fenomena tentang apa yang dialami oleh subjek penelitian dengan cara mendeskripsikannya dengan deskripsi dalam bentuk kata-kata dan bahasa (Moleong, 2015:6). Dalam pengumpulan data, peneliti menggunakan metode simak catat. Data yang telah terkumpul kemudian dianalisis menggunakan konsep religi Koentjaraningrat. Data yang digunakan pada penelitian ini berupa dialog dan screenshot potongan adegan dalam anime Noragami yang menggambarkan bentuk kepercayaan atau praktik ajaran Shinto. Sumber data yang digunakan dalam penelitian ini adalah anime Noragami season pertama (2014) 12 episode dan season kedua (2015) 13 episode yang disutradarai oleh Kotaro Tamura dengan durasi tayang 23 menit setiap episodenya. 
Teknik pengumpulan data yang dilakukan oleh penulis dalam memperoleh data adalah menggunakan teknik simak dan teknik catat. Teknik simak merupakan Teknik yang berwujud teknik sadap, karena penyimakan diwujudkan dengan penyadapan. Jadi, penulis dalam mendapatkan data dilakukan dengan menyadap pembicaraan dan penggunaan bahasa yang dilakukan oleh seseorang (Mahsun, 2005:92) dan teknik catat merupakan teknik lanjutan yang dilakukan ketika menerapkan teknik simak. Penulis mencatat hal-hal yang telah disimak sebelumnya, yang berkaitan dan relevan dengan penelitiannya (Mahsun, 2005:93).

\section{HASIL DAN PEMBAHASAN}

\subsection{Bentuk-bentuk kepercayaan masyarakat Jepang dalam Shinto, meliputi:}

3.1.1 Kepercayaan terhadap sosok siluman

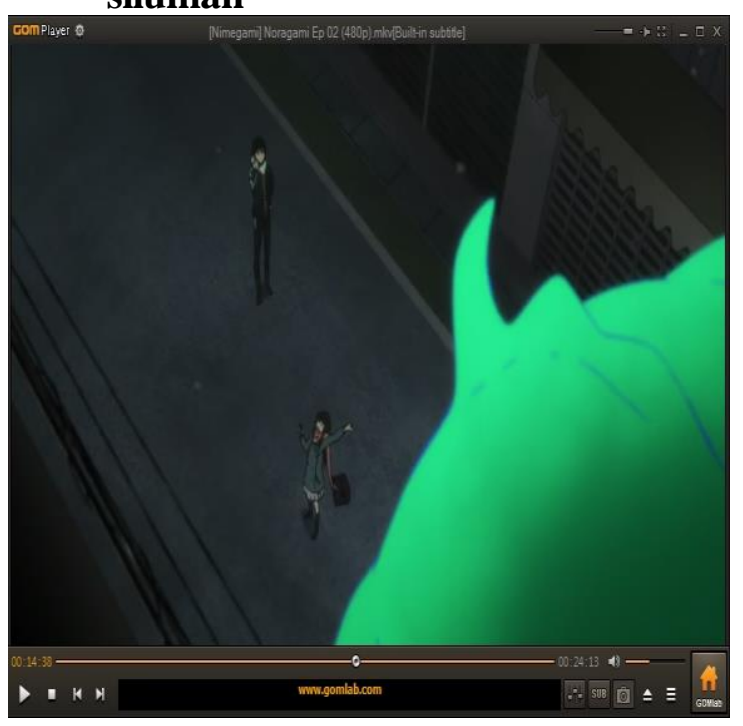

Gambar 1. Hiyori yang menemukan sosok siluman

\begin{tabular}{|l|l|}
\hline Hiyori & $\begin{array}{l}\text { ででででも神器は死霊 } \\
\text { だって” }\end{array}$ \\
\hline
\end{tabular}

\begin{tabular}{|l|l|}
\hline & $\begin{array}{l}\text { De de de demo shinki wa } \\
\text { shiryou date }\end{array}$ \\
\hline Yato & $\begin{array}{l}\text { “Ta ta ta tapi, katamu } \\
\text { Shinki berasal dari roh } \\
\text { orang mati” }\end{array}$ \\
\hline “ありや念も呪も絡んだ \\
塊たたのあやかしだ 見 \\
りや分かんだ” \\
\hline $\begin{array}{l}\text { Arya nen mo noroi mo } \\
\text { karanda katamari tada no } \\
\text { avakashi da miru wa } \\
\text { wakarundarou }\end{array}$ \\
$\begin{array}{l}\text { 'Dia itu hanya ayakashi } \\
\text { biasa yang terbentuk atas } \\
\text { gumpalan emosi dan } \\
\text { kutukan !. Dilihat saja } \\
\text { harusnya kau tau kan ?! }\end{array}$ \\
\hline
\end{tabular}

Pada dialog di atas Hiyori yang menghubungi Dewa Yato mengatakan bahwa dia telah menemukan sosok roh untuk sang dewa. Mendengar pernyataan tersebut kemudian Dewa Yato segera menemui Hiyori. Melihat apa yang ditemukan Hiyori bukan sesosok roh melainkan siluman yang disebut ayakashi membuat Dewa Yato memilih untuk melarikan diri bersama dengan Hiyori. Dalam pelariannya Dewa Yato menyampaikan protesnya kepada Hiyori karena tidak bisa membedakan mana roh orang mati dan mana ayakashi. Berdasarkan analisis terhadap dialog tersebut menunjukkan bahwasannya terdapat bentuk kepercayaan akan adanya sosok gaib berupa siluman. Koentjaraningrat (1998:206) menyebutkan bahwa sebagai penghuni dunia gaib hantu dan sosok lainnya dibayangankan memiliki wujud yang 
berbeda beda dengan berbagai penjelmaan, mulai dari yang sangat mengerikan sampai yang berwajah cantik.

Siluman yang dalam masyarakat Jepang dikenal sebagai ayakashi pada kasus ini digambarkan lahir karena kumpulan emosi negatif manusia serta memiliki wujud layaknya binatang dengan ukuran yang beranekaragam. Di dalam kisah masyarakat Jepang sendiri ayakashi merupakan sejenis makhluk gaib yang muncul di atas permukaan air dan juga bisa diartikan sebagai "fenomena aneh di lautan". Mereka dipercaya sebagai sosok yang sering kali menyerang para nelayan hingga menenggelamkan kapal di lautan (Hyakumonogatari.com).

\subsubsection{Kepercayaan terhadap jiwa atau} roh orang mati

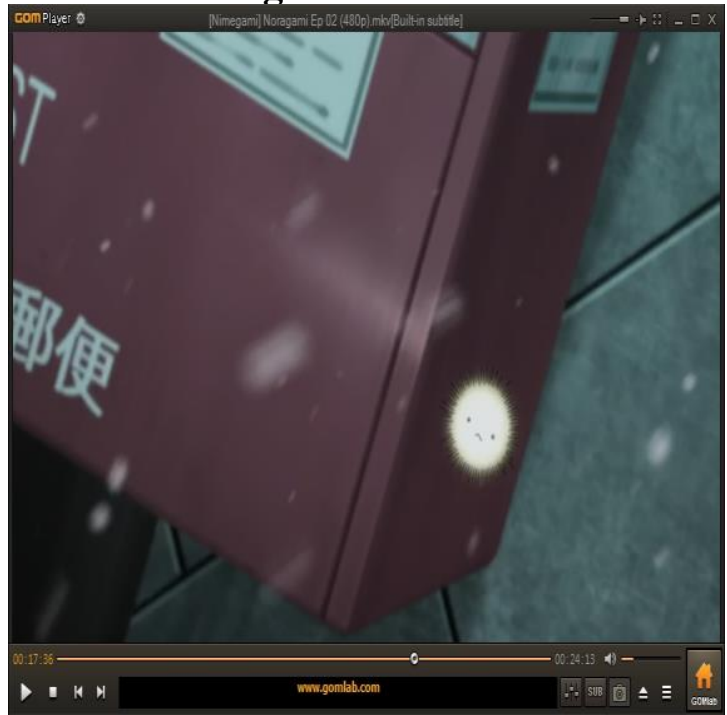

Gambar 2. Sosok roh yang ditemukan oleh Dewa Yato

\begin{tabular}{|l|l|}
\hline Hiyori & $\begin{array}{l}\text { “だって夜トー人じゃ } \\
\text { 何もできないんですよ } \\
\text { ね” }\end{array}$ \\
\hline \multirow{6}{*}{$\begin{array}{l}\text { Datte Yato hitorija } \\
\text { nanimo dekinain } \\
\text { desuyone }\end{array}$} \\
\hline $\begin{array}{l}\text { Tapi Yato sendirian } \\
\text { tidak bisa melakukan } \\
\text { apa-apa kan ?! }\end{array}$ \\
\hline
\end{tabular}

\begin{tabular}{|c|c|}
\hline \multirow[t]{2}{*}{ Yato } & $\begin{array}{l}\text { “うるせえなだからず } \\
\text { っと探してんだよ 俺 } \\
\text { のしん..” }\end{array}$ \\
\hline & $\begin{array}{l}\text { Uruseena dakara zutto } \\
\text { sagashitendayo ore no } \\
\text { shin.. }\end{array}$ \\
\hline & $\begin{array}{l}\text { "Berisik.. karena itu aku } \\
\text { selalu mencari Shinki } \\
\text { milik-" }\end{array}$ \\
\hline & $\begin{array}{l}\text { “男見たとこ 十代そ } \\
\text { こそこのガキ”, }\end{array}$ \\
\hline & $\begin{array}{l}\text { Otoko mita koto judai } \\
\text { soko soko no gaki }\end{array}$ \\
\hline & $\begin{array}{l}\text { 'Laki-laki kira-kira anak } \\
\text { berusia remaja, }\end{array}$ \\
\hline & $\begin{array}{l}\text { “ちよっと面倒くせえ } \\
\text { 時期か” }\end{array}$ \\
\hline & $\begin{array}{l}\text { Chotto mendoukusee jiki } \\
\text { ka }\end{array}$ \\
\hline & $\begin{array}{l}\text { Usia yang sedikit } \\
\text { merepotkan.. }\end{array}$ \\
\hline Hiyori & "夜卜” \\
\hline & Yato \\
\hline & 'Yato!' \\
\hline Yato & “あいつにする” \\
\hline & Aitsu ni suru \\
\hline & Akan ku pilih dia \\
\hline
\end{tabular}

Pada dialog di atas dalam pelariannya dari kejaran ayakashi yang sebelumnya Dewa Yato dan Hiyori temui, dari kejauhan terlihat sebuah sesosok roh yang berwujud layaknya butiran salju sedang terapung melayang sendirian. Dewa Yato yang melihat sosok tersebut kemudian memperkirakan bahwa roh tersebut berasal dari seorang anak berusia belasan tahun yang telah meninggal. Setelah melakukan perhitungan yang cukup matang Dewa Yato memutuskan mengangkat roh tersebut menjadi roh pelayannya (shinki). Berdasarkan analisis terhadap dialog tersebut menunjukkan 
bahwasannya masyarakat Jepang percaya akan adanya sosok gaib berupa roh dari mereka yang telah mati. Koentjaraningrat

(1998:208) memaparkan bahwa jiwa yang telah meninggalkan tubuh yang mati kemudian menjadi makhluk halus yang memiliki kepribadian sendiri sebagai ruh. Dalam kepercayaan masyarakat Jepang roh orang mati disebut sebagai shiryou ( 死霊). Di dalam kisah klasik masyarakat Jepang shiryou sejatinya merupakan sejenis hantu (youkai) dari orang mati. Hal ini sesuai dengan kanji (shi) yang tersemat pada namanya. Mereka percaya bahwa shiryou akan menunjukkan sosoknya kepada teman atau kerabat dekatnya hanya untuk menyampaikan selamat tinggal atau untuk membawa orang yang mereka cintai pergi bersama ke dunia kematian (Yokai.com/shiryō).

\subsubsection{Kepercayaan terhadap dewa}

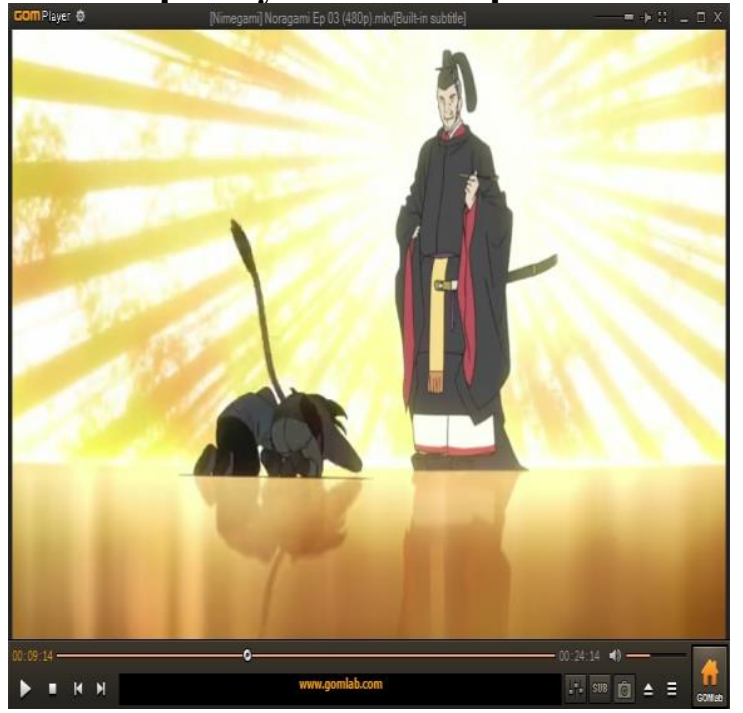

Gambar 3. Hiyori dan Yukine bersujud di hadapan Dewa Tenjin

\begin{tabular}{|l|l|}
\hline Tenjin & $\begin{array}{l}\text { “東風吹かば 匂いおこ } \\
\text { せよ 梅の花” }\end{array}$ \\
\hline & $\begin{array}{l}\text { kochifukaba nioi okoseyo } \\
\text { ume no hana }\end{array}$ \\
\hline
\end{tabular}

\begin{tabular}{|c|c|}
\hline & $\begin{array}{l}\text { "Saat angin timur } \\
\text { berhembus, dia menyebar } \\
\text { aromamu, wahai bunga } \\
\text { plum" }\end{array}$ \\
\hline \multirow[t]{3}{*}{ Hiyori } & “う.. 梅が” \\
\hline & U.. ume ga \\
\hline & 'Bu.. bunga plum-nya ?' \\
\hline \multirow[t]{3}{*}{ Tenjin } & $\begin{array}{l}\text { “主人なしとて 春を忘 } \\
\text { るな” }\end{array}$ \\
\hline & $\begin{array}{l}\text { Aruji nashi tote haru wo } \\
\text { wasureruna }\end{array}$ \\
\hline & $\begin{array}{l}\text { Meski tanpa tuanmu, } \\
\text { jangan lupakan musim } \\
\text { semi. }\end{array}$ \\
\hline \multirow[t]{3}{*}{ Hiyori } & $\begin{array}{l}\text { “こ この歌は菅原道真 } \\
\text { もしかして 学問の神 } \\
\text { 天神様” }\end{array}$ \\
\hline & $\begin{array}{l}\text { Ko.. kono uta wa } \\
\text { Sugawara no Michizane.. } \\
\text { moshikashite.. Gakumon } \\
\text { no Kami Tenjin-sama }\end{array}$ \\
\hline & $\begin{array}{l}\quad \text { Pu.. Puisi ini milik } \\
\text { Sugawara no Michizane.. } \\
\text { mungkinkah.. Dewa Ilmu } \\
\text { Pengetahuna Tenjin- } \\
\text { sama?!' }\end{array}$ \\
\hline \multirow[t]{3}{*}{ Tenjin } & “あれ 分かっちやった \\
\hline & Are.. wakachatta \\
\hline & 'Oh.. Kau sudah tahu?' \\
\hline \multirow[t]{3}{*}{$\begin{array}{l}\text { Hiyori dan } \\
\text { Yukine }\end{array}$} & “神よ" \\
\hline & Kamiyo \\
\hline & 'Oh dewa' \\
\hline
\end{tabular}

Pada dialog di atas Dewa Yato bersama dengan Hiyori dan roh pelayannya Yukine mengunjungi sebuah kuil. Setibanya di komplek kuil tiba-tiba mereka disambut dengan lantunan puisi dari seseorang yang menyembunyikan sosoknya. Sang pelantun baru menunjukkan sosoknya setelah Hiyori menyadari bahwa puisi tersebut merupakan milik Sugawara no 
Michizane atau yang dikenal sebagai Tenjin sang Dewa Ilmu Pengetahuan. Berdasarkan analisis terhadap dialog di atas menunjukkan bahwa di dalam diri masyarakat Jepang terdapat kepercayaan terhadap sosok gaib berupa dewa. Koentjaraningrat (1998:204) mendefinisikan dewa sebagai makhluk yang oleh manusia dibayangkan mempunyai nama, bentuk, ciri-ciri, sifatsifat dan kepribadian yang tegas. Masyarakat Jepang sendiri menyebut dewa-dewa yang mereka sembah sebagai Kami. Dalam praktiknya istilah Kami bisa merupakan personifikasi dari gejala alam yang dianggap mempunyai spirit selain itu Kami juga bisa berarti manusia. Hal ini senada dengan salah satu mitologi bangsa Jepang bahwa terkait sosok Kami yang berasal dari manusia yaitu Sugawara no Michizane atau yang sekarang dikenal sebagai Tenjin. Sebelum diangkat menjadi dewa oleh masyarakat sejatinya Tenjin merupakan seorang manusia bernama di zaman Heian. Michizane merupakan seorang sarjana, penyair dan politikus cerdas dan terpelajar. Setelah Michizane meninggal terjadi musibah serta wabah yang menyerang ibu kota dan menyebabkan banyak anggota keluarga Fujiwara yang tewas. Pihak kerajaan menyimpulkan bahwa tragedi tersebut disebabkan oleh roh Michizane yang marah. Oleh karena itu demi menenangkan roh tersebut kemudian mereka mengembalikan gelar-gelarnya, menjadikannya dewa dan diberi nama Tenman-Tenjin atau yang biasa disingkat menjadi Tenjin (Japanesestation.com).

\subsection{Cerminan praktik ajaran Shinto \\ 3.2.1 Praktik Penyucian}

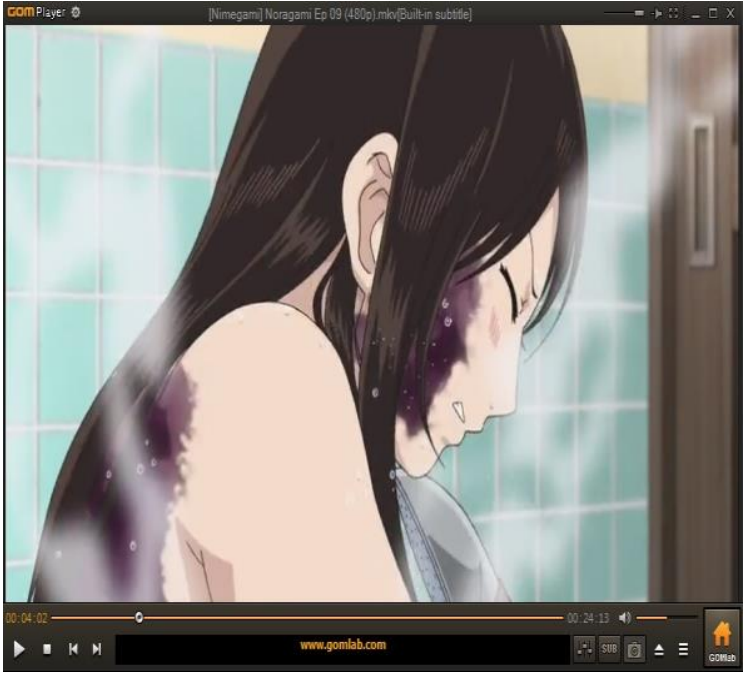

Gambar 4. Hiyori yang melakukan penyucian karena telah terpapar yasumi

\begin{tabular}{|c|c|}
\hline Daikoku & $\begin{array}{l}\text { "小福ひよりちゃんの } \\
\text { ヤスミ清めてやれ" }\end{array}$ \\
\hline & $\begin{array}{l}\text { Kofuku Hiyori-chan no } \\
\text { yasumi kiyomete yare }\end{array}$ \\
\hline & $\begin{array}{l}\text { Kofuku tolong } \\
\text { bersihkan yasumi milik } \\
\text { Hiyori }\end{array}$ \\
\hline \multirow[t]{3}{*}{ Kofuku } & $\begin{array}{l}\text { “この水庭の湧き水を } \\
\text { 直接引いてるから, さ } \\
\text { 体洗って” }\end{array}$ \\
\hline & 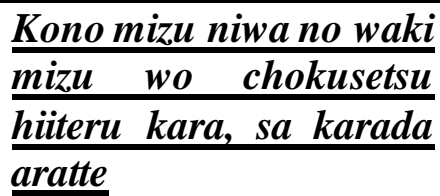 \\
\hline & $\begin{array}{l}\text { Air ini terhubung } \\
\text { langsung dengan mata } \\
\text { air, jadi cepat } \\
\text { bersihkan badanmu, }\end{array}$ \\
\hline
\end{tabular}

Pada dialog di atas Hiyori yang ikut tercemar yasumi (impurity) karena menolong Dewa Yato kemudian pergi menuju kediaman Dewa Kofuku untuk meminta pertolongan kepadanya. Sesampainya di sana hanya Hiyori yang diijinkan masuk ke dalam rumah sang dewa sedangkan Dewa Yato yang telah tercemar parah hanya diperbolehkan 
berada di luar. Hiyori lantas di bawa ke kamar mandi oleh Dewa Kofuku untuk segera melakukan penyucian terhadap yasumi di tubuhnya. Penyucian tersebut menggunakan air yang bersumber dari mata air di sekitar kediaman sang dewa. Berdasarkan analisi terhadap dialog tersebut prosesi penyucian yang dilakukan oleh Hiyori mencerminkan bentuk praktik penyucian dalam kepercayaan Shinto yang dikenal sebagai misogi. Misogi sejatinya merupakan praktik penyucian yang dilakukan di tempat yang memiliki sumber mata air alami seperti halnya air terjun, danau dan sungai. Tujuan dari prosesi tersebut yaitu untuk menghilangkan kegare dan mengembalikan kesucian jiwa raga seseorang sehingga bisa kembali mendekatkan diri ke Kami.

\subsubsection{Pemberian Persembahan}

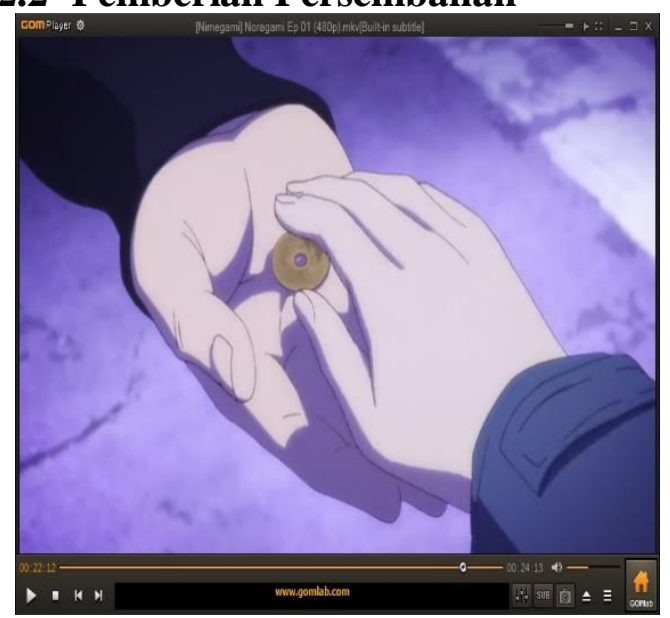

Gambar 5. Hiyori yang memberikan uang persembahan kepada Dewa Yato

\begin{tabular}{|l|l|}
\hline Yato & “金” \\
\hline & Kane \\
\hline & 'Uang \\
\hline Hiyori & $\begin{array}{l}\text { “お金とるんです } \\
\text { か ” }\end{array}$ \\
\hline & $\begin{array}{l}\text { Okane torundesuka } \\
\text { ?! }\end{array}$ \\
\hline
\end{tabular}

\begin{tabular}{|c|c|}
\hline & $\begin{array}{l}\text { ' Kau meminta } \\
\text { bayaran ?! }\end{array}$ \\
\hline \multirow[t]{3}{*}{ Yato } & $\begin{array}{l}\text { “ただでかなう願 } \\
\text { いなんかある } \\
\text { これでてを売って } \\
\text { やろ” }\end{array}$ \\
\hline & $\begin{array}{l}\text { Tada de kanau negai } \\
\text { nanka aru ka Kore } \\
\text { de te wo utte yaro }\end{array}$ \\
\hline & $\begin{array}{lr}\text { Mana } & \text { ada } \\
\text { permohonan } & \text { yang } \\
\text { terkabul } & \text { dengan } \\
\text { gratis. Bagaimana } \\
\text { kalau dengan segini } \\
\text { ? }\end{array}$ \\
\hline \multirow[t]{3}{*}{ Hiyori } & $\begin{array}{l}\text { “ご五万 五十万 } \\
\text { そんな大金” }\end{array}$ \\
\hline & $\begin{array}{lrr}\text { Go go } & \text { man go } \\
\text { jyuuman } & \text { sonna } \\
\text { taikin } & & \\
\end{array}$ \\
\hline & $\begin{array}{l}\text { 'li.. lima puluh ribu, } \\
\text { lima ratus ribu, uang } \\
\text { sebanyak itu..' }\end{array}$ \\
\hline \multirow[t]{3}{*}{ Yato } & $\begin{array}{l}\text { “おろかもの 俺は } \\
\text { 神たジ゙賽銭は五円 } \\
\text { だと決ってんだろ } \\
\text { うが” }\end{array}$ \\
\hline & $\begin{array}{l}\text { Orokamono ore wa } \\
\text { kami dazo saisen wa } \\
\text { go en dato kimatten } \\
\text { darou ga }\end{array}$ \\
\hline & $\begin{array}{l}\text { Dasar bodoh, aku } \\
\text { ini dewa loh, sudah } \\
\text { jelaskan kau harus } \\
\text { memberi } 5 \text { yen } \\
\text { sebagai } \\
\text { persembahan!' }\end{array}$ \\
\hline \multirow[t]{3}{*}{ Hiyori } & $\begin{array}{l}\text { “五つ, あつ えつ } \\
\text { と” }\end{array}$ \\
\hline & Go a etto \\
\hline & 'Li.. ah.. emm' \\
\hline
\end{tabular}

Pada dialog di atas Hiyori yang tersadar telah diselamatkan oleh Dewa Yato 
kemudian menanyakan mengenai kondisi dirinya. Menurut Dewa Yato sudah sewajarnya bagi manusia untuk memberikan persembahan kepada dewa pada saat mereka meminta suatu permohonan. Oleh sebab itu Hiyori kemudian memberikan uang sebesar lima yen kepada Dewa Yato atas permohonannya agar bisa kembali menjadi manusia normal. Pemberian uang kepada Dewa Yato yang ditunjukan pada dialog merupakan bentuk cerminan dari praktik saisen yang biasa warga Jepang lakukan pada saat mereka akan berdoa di kuil (jinja). Pemberian uang persembahan memiliki maksud untuk menghormati dan membuat dewa (Kami) senang sehingga mereka bisa segera mengabulkan permohonan yang telah seseorang panjatkan kepadanya.

\subsubsection{Praktik Berdoa}

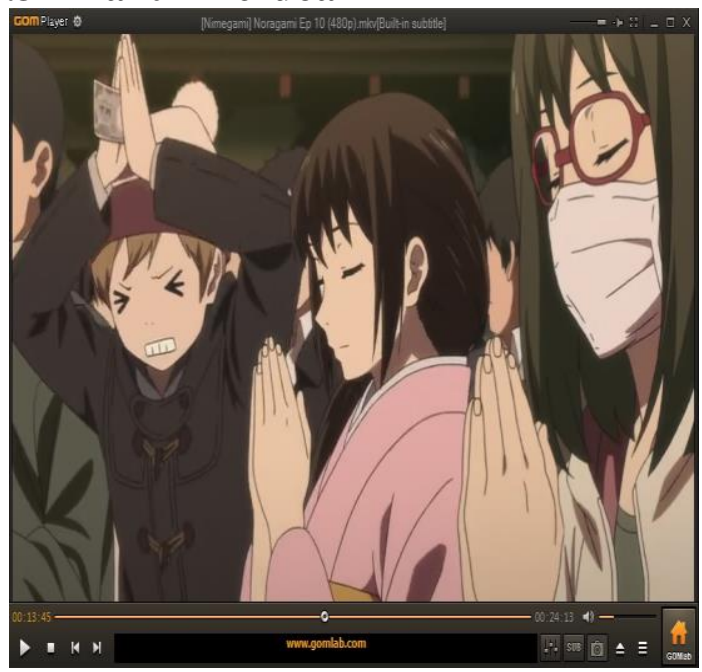

Gambar 6. Hiyori dan teman-teman yang berdoa di kuil Dewa Tenjin

\begin{tabular}{|c|lr|}
\hline Yama & “今年はお賽銭弾む \\
& の受験ついでに高校 \\
& デビューすっかなき \\
& たれモテ期” \\
\hline & Kotoshi wa r osaisen \\
& hazumuno r juuken \\
& tsuideno r & koukou \\
\hline
\end{tabular}

\begin{tabular}{|c|c|}
\hline & $\begin{array}{l}\text { debyuusukkana kitare } \\
\text { moteki }\end{array}$ \\
\hline & $\begin{array}{l}\text { Tahun ini aku akan } \\
\text { mempersembahkan } \\
\text { banyak uang, Soalnya } \\
\text { selain ujian kita juga } \\
\text { akan memulai masa } \\
\text { SMA. Semoga aku } \\
\text { populer, }\end{array}$ \\
\hline \multirow[t]{3}{*}{ Ami } & $\begin{array}{l}\text { “はしやぐな馬鹿. 高 } \\
\text { 校ってもうちらはク } \\
\text { ラスごと繰りあげる } \\
\text { んだってぱ” }\end{array}$ \\
\hline & $\begin{array}{l}\text { Hashaguna baka } \\
\text { Koukouttemo uchi ra } \\
\text { wa kurasu goto guri } \\
\text { agerundattepa }\end{array}$ \\
\hline & $\begin{array}{l}\text { 'Jangan berisik bodoh, } \\
\text { meski dibilang SMA } \\
\text { semua orang di kelas } \\
\text { kita hanya akan seperti } \\
\text { naik kelas...' }\end{array}$ \\
\hline \multirow[t]{3}{*}{ Yama } & $\begin{array}{l}\text { “モテ期モテ期モテ } \\
\text { 期モテ期もしくはモ } \\
\text { テ期ダメならモ } \\
\text { 期” }\end{array}$ \\
\hline & $\begin{array}{l}\text { Moteki Moteki Moteki } \\
\text { moshiku wa Moteki } \\
\text { dame nara Moteki }\end{array}$ \\
\hline & $\begin{array}{l}\text { "Populer! Semoga aku } \\
\text { jadi populer" }\end{array}$ \\
\hline \multirow[t]{2}{*}{ Hiyori } & $\begin{array}{l}\text { “無事高校生になれ } \\
\text { ますように. いまま } \\
\text { でなんとなくお参り } \\
\text { してたけどこれから } \\
\text { も皆と一緒に楽しく } \\
\text { いられますように” }\end{array}$ \\
\hline & $\begin{array}{ll}\text { Buji } & \text { koukousei } \\
\text { naremasu } & \text { youni } \\
\text { made } & \text { nantonaku } \\
\text { omairihita kedo } & \text { kore } \\
\text { kara mo minna to } \\
\text { isshouni tanoshiku } \\
\text { iraremasuyouni. }\end{array}$ \\
\hline
\end{tabular}




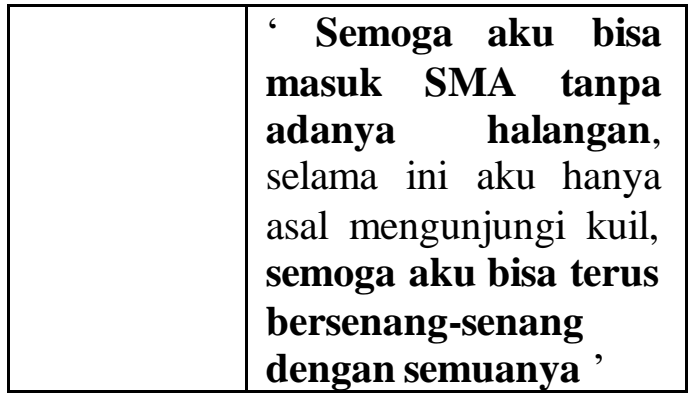

Pada dialog 20 Hiyori dan dua orang temannya yaitu Ami dan Yama pergi ke Kuil Yushima Tenjin dalam rangka hatsumode atau mengunjungi kuil untuk berdoa pada malam pergantian tahun. Di perjalanan menuju altar berdoa Yami mengatakan kepada Hiyori dan Ami bahwa dia akan memberikan uang persembahan yang banyak dan mengharapkan dirinya menjadi populer di debut SMA-nya nanti. Sesampainya di altar Hiyori memohon agar dilancarkan masuk SMA-nya serta bisa terus bersenang-senang dengan semuanya. Sedangkan Yama masih sama seperti sebelumnya yang mana menginginkan menjadi siswi populer. Secara teknikal praktik berdoa orang Jepang di kuil di mulai dengan membersihkan diri dengan malakukan temizu terlebih dahulu ketika baru tiba di kuil. selesai melakukan temizu kemudian peziarah segera menuju altar pemujaan. Sesampainya di altar mereka akan melemparkan sejumlah uang ke dalam saisen bako sebagai wujud persembahan kepada Kami baru setelah itu mereka mulai memanjatkan doa atau permohonan mereka kepada Kami.

\section{KESIMPULAN}

Pada penelitian ini terdapat beberapa poin terkait bentuk kepercayaan serta praktik keagamaan dalam ajaran Shinto yaitu:

1. Shinto meyakini bahwa dunia ini terbagi atas dua dimensi yang saling berdampingan yaitu dimensi tempat para manusia hidup dan dimensi tidak kasatmata tempat bagi makhluk gaib seperti roh orang mati, hantu atau siluman serta para dewa bersemayam.

2. Shinto memandang bahwa para dewa (Kami) merupakan sosok yang terlahir karena adanya doa (harapan) dari manusia. Sedangkan siluman (ayakashi) merupakan sosok yang terlahir dari kumpulan emosi negatif manusia.

3. Shinto menitik beratkan kepada kesucian sebagai salah satu sarat dalam rangka mendekatkan diri dengan Kami, oleh sebab itu lahir praktik penyucian. Setelah seseorang dianggap suci maka dia bisa melakukan aktivitas kebaktian lainnya seperti melakukan pemberian persembahan serta berdoa kepada Kami.

Berd asarkan hasil analisis, dapat disimpulkan bahwa:

Bentuk kepercayaan dalam ajaran Shinto yang ada di anime Noragami meliputi:

a. Kepercayaan terhadap keberadaan siluman atau hantu,

b. Kepercayaan terhadap roh orang mati,

c. Kepercayaan terhadap ad anya sesosok dewa.

Sedangkan untuk bentuk praktik ajaran Shinto yang tercermin di anime noragami berupa:

d. Praktik penyucian,

e. Pemberian Persembahan,

f. Praktik Berdoa.

\section{DAFTAR PUSTAKA}

Afrianti, Muflikhatun. 2018. "Dewi Izanami dan Dewa Izanagi dalam Agama Shinto Jepang (Studi Semiotik Dalam Film Noragami Aragoto)" Religi Vol.14 nomor 2-2018: hal.169:193. http://ejournal.uinsuka.ac.id/ushuluddin/Religi/article/vie w/1710 (diakses pada 8 September 2019). 
Danandjaja, James. 1997. Folklor Jepang:

Dilihat dari Kacamata Indonesia.

Jakarta: PT. Pustaka Utama Grafiti.

Ghazali, Adeng Muchtar. 2004. Agama dan

Keberagamaan dalam Konteks

Perbandingan Agama. Bandung: CV

Pustaka Setia.

Haryanti, Pitri. 2013. All About Japan.

Yogyakarta: Andi Offset.

Hyakumonogatari.com. (2013, 21 Agustus). What Does Ayakashi Mean In English. Diakses pada 7 Desember 2020, https://hyakumonogatari.com/2013/08/21/ what-does-ayakashi-mean-in-english/

Japanesestation.com. (2015, 14 Desember). Mengenal Lebih Dekat Tentang Kepercayaan Shinto Legenda Di Balik Dewa Dewi Dalam Noragami. Diakses pada 13 Mei 2020, https://japanesestation.com/animemanga/anime/mengenal-lebih-dekattentang-kepercayaan-shinto-legenda-dibalik-dewa-dewi-dalam-noragami

Koentjaraningrat. 1987. Sejarah Teori Antropologi. Jakarta: Penerbit Universitas Indonesia.

Koentjaraningrat. 1998. Pengantar Antropologi II. Jakarta: PT Rineka Cipta.

Kutha Ratna, Nyoman. 2011. Antropologi

Sastra: Peranan Unsur-Unsur

Kebudayaan dalam Proses Kreatif.

Yogyakarta: Pustaka Pelajar.

Mahsun. 2005. Metode Penelitian Bahasa. Jakarta: PT Raja Grafindo Persada.
Mansur, Sufa'at. 2011. Agama-Agama Besar Masa Kini. Yogyakarta: Pustaka Pelajar.

Moleong, Lexy J. 2015. Metodologi Penelitian Kualitatif. Bandung. PT. Remaja Rosdakarya Offset.

Nadroh, Siti dan Syaiful Azmi. 2015. Agama Agama Minoritas. Jakarta: Kencana.

Siswantoro. 2014. Metode Penelitian Sastra. Yogyakarta: Pustaka Pelajar.

Sugono, Dendy dkk. 2008. Kamus Bahasa Indonesia. Jakarta: Pusat Bahasa.

Sutardi, Tedi. 2007. Antropologi: Mengungkap Keberagaman Kebudayaan. Bandung: PT. Setia Purna Inves.

Yokai.com/shiryō. Diakses pada 6 Desember 2020 , http://yokai.com/shiryou/?fbclid=IwAR 0kZ_SpKuy2ghNFhQSMdjU3thVx7W G1yDIo9XjFr3tD3x5XYhd5NLuNl_E 